\title{
Changes in Hepatic Enzyme Activities Related to Ethanol Metabolism in Mice Following Chronic Ethanol Administration
}

\author{
Ritsuko Kishimoto,* Ikuko Fujiwara, Seiichi Kitayama, \\ Kiyoshi Goda, and Yozo NaKata ${ }^{1}$ \\ Faculty of Nutrition, Kobe Gakuin University, \\ Nishi-ku, Kobe 651-21, Japan \\ ${ }^{1}$ School of Medical Science, Osaka University, \\ Yamadaoka, Suita 565, Japan
}

(Received September 7, 1994)

Summary Male mice of three strains, C57BL, DBA and $\mathrm{C} 3 \mathrm{H} / \mathrm{He}$, were fed on commercial food with $10 \%(\mathrm{v} / \mathrm{v})$ ethanol solution as drinking liquid ad libitum for eighty days, and the changes in the activities of enzymes in the metabolic pathway of ethanol in the liver were examined. $\mathrm{C} 57 \mathrm{BL}$ and $\mathrm{C} 3 \mathrm{H} / \mathrm{He}$ mice showed a preference for drinking the $10 \%$ (v/v) ethanol solution, while DBA mice did not. The ethanol intake $\mathrm{g} / \mathrm{g}$ of body weight of $\mathrm{C} 3 \mathrm{H} / \mathrm{He}$ mice showed the highest value among all three strains and that of C57BL mice tended to show higher value than that of DBA mice. The liver weights of $\mathrm{C} 57 \mathrm{BL}$ and $\mathrm{C} 3 \mathrm{H} / \mathrm{He}$ mice increased significantly following chronic ethanol administration, but that of DBA did not. The cytosolic enzyme alcohol dehydrogenase (ADH) showed no changes in any of the strains following chronic ethanol administration. The microsomal ethanol-oxidizing system (MEOS) of C57BL mice exhibited approximately 2-fold higher activity compared to that of DBA and $\mathrm{C} 3 \mathrm{H} / \mathrm{He}$ mice but did not increase in any strain following chronic ethanol administration. However, the microsomal aniline hydroxylase activity in the liver increased significantly in $\mathrm{C} 57 \mathrm{BL}$ and $\mathrm{C} 3 \mathrm{H} / \mathrm{He}$ mice following chronic administration of ethanol. The microsomal cytochrome P-450 content also tended to slightly increase in the same strains of mice. It seemed that cytochrome P-450IIE1 was induced in the liver microsomes of these strains. Total aldehyde dehydrogenase (AlDH) activities together with high- $K_{\mathrm{m}}$ AlDH activity increased markedly in the microsomes of C57BL mice and tended to increase in $\mathrm{C} 3 \mathrm{H} / \mathrm{He}$ mice, while it did not change in DBA mice following chronic ethanol administration. In the mitochondria of C57BL, total AlDH activities increased slightly and high- $K_{\mathrm{m}}$ AlDH activities tended to increase. These mitochondrial AlDH

* To whom correspondence should be addressed. 
activities of $\mathrm{C} 3 \mathrm{H} / \mathrm{He}$ and DBA mice tended to increase following chronic ethanol administration. The cytosolic AlDH activity showed no changes in any strain of mice following chronic ethanol administration. It seemed that in the microsomes, the activities of enzymes related to oxidation of ethanol increased in $\mathrm{C} 57 \mathrm{BL}$ and $\mathrm{C} 3 \mathrm{H} / \mathrm{He}$ mice, which tended to consume a large amount of ethanol, and did not in DBA mice which tended to consume a small amount of it. It seemed that the increases in activities of enzymes related to oxidation of acetaldehyde in the microsomes and in the mitochondria were responsible for the strain difference.

Key Words alcohol intoxication, chronic ethanol administration, strain difference of metabolic adaptation, alcohol dehydrogenase, aldehyde dehydrogenase, microsomal ethanol-oxidizing system, cytochrome P-450, aniline hydroxylase

Ethanol increases the fluidity of neuronal cell membranes, and this is responsible for its acute effects. Chronic exposure to ethanol alters normal fluidity of neuronal cell membranes (tolerance to ethanol), and thus produces physical dependence. On the other hand, the body breaks down ethanol mainly in the liver as it is a foreign substance. Ethanol is known to be oxidized to acetaldehyde in the liver mainly by two enzyme systems. Thus, under normal conditions or drinking a small amount of ethanol, ethanol could be oxidized by constitutional enzymes such as alcohol dehydrogenase (ADH), present in the fraction of the cytoplasm (cytosol). However, chronic consumption or a large amount of ethanol would lead to induction of the hepatic microsomal drug-metabolizing system such as the NADPH-dependent microsomal ethanol-oxidizing system (MEOS) by proliferation of smooth endoplasmic reticulum (1). The cytochrome P-450 is an indispensable factor of MEOS (2). Cytochrome P-450IIE1, which showed high aniline hydroxylase activity $(3,4)$, was found to be induced in mice by ethanol exposure (5). Acetaldehyde is known to be almost exclusively oxidized to acetate by liver aldehyde dehydrogenase (AlDH). Low- $K_{\mathrm{m}}$ and high- $K_{\mathrm{m}}$ AlDH activities were detected in the mitochondria, microsome and cytosol fractions of the rat liver (6). It is seemed that low- $K_{\mathrm{m}}$ mitochondrial AlDH plays the major role in acetaldehyde metabolism (7). While the role of AIDH in the hepatic microsomal fraction is unknown. Acetaldehyde plays an important role in the toxic and pharmacologic effects of alcohol.

Circadian rhythmicity of the biological response to and disposition of ethanol have been reported in mice (8). The question arises, therefore, as to whether or not a circadian rhythm exist in hepatic alcohol metabolism. In our previous study (9), the metabolic activities of the oxidation of ethanol and acetaldehyde in liver microsomes of $\mathrm{C} 3 \mathrm{H} / \mathrm{He}$ mice showed diurnal changes; both metabolic activities increased at night during which mice are active. It should be determined whether the same is true for any other strain of mice. 
It is well-known that C57BL mice show a preference for drinking alcohol solutions, while DBA mice show significant avoidance. It has been reported that there were differences in the induction of hepatic microsomal drug-metabolizing system between both the strains of mice (10-12), and Sheppard et al. (13) reported that the liver of $\mathrm{C} 57 \mathrm{BL} / 6 \mathrm{~J}$ mice exhibited a 2- to 3-fold greater aldehyde-oxidizing capacity compared to that of DBA/9J mice. Eriksson et al. (14) reported that the concentrations of blood and liver acetaldehyde of C57BL mice were lower than that of DBA after ethanol dosing. This raises the possibility that there may be a relationship between hepatic metabolic activity and the addiction to alcohol.

In this study, three mouse strains, C57BL, DBA and $\mathrm{C} 3 \mathrm{H} / \mathrm{He}$, which show different behavioral phenomena with regard to alcohol preference, were used to study the changes in enzymatic activities in the metabolic pathways of ethanol in the liver in response to chronic administration of ethanol.

\section{EXPERIMENTAL}

Animals. Twenty 5-week-old male mice from each of $\mathrm{C} 57 \mathrm{BL} / 6 \mathrm{NCrj}$ (C57BL), DBA/2NCrj (DBA) and $\mathrm{C} 3 \mathrm{H} / \mathrm{HeNCrj}(\mathrm{C} 3 \mathrm{H} / \mathrm{He})$ strains were obtained from Charles River Japan, Ltd. The mice were fed with commercial MF food (Oriental Yeast Co., Ltd.) and ten mice each of the three strains were given water (Control), while the other the ten mice each were given $10 \%(\mathrm{v} / \mathrm{v})$ ethanol solution (Ethanol) ad libitum for eighty days. The animal housing conditions were as follows: 12-h light-dark cycle with lights on from $8: 00$ to $20: 00$, temperature of $22.5 \pm 0.5^{\circ} \mathrm{C}$ and humidity of $50-60 \%$. Ethanol $\left(\mathrm{C}_{2} \mathrm{H}_{5} \mathrm{OH}\right.$, purity $>99.5 \%$ and specific gravity of 0.793 ) was purchased from Nacalai Tesque Co. The body weight of mice and the amounts of food and liquid consumption by the two mice in a cage were measured and recorded at 2 p.m. and the amount of food and liquid consumption per mouse were calculated during the experimental period. Mice were then sacrificed by cervical dislocation at the end of this period at $10 \mathrm{a} . \mathrm{m}$., and the enzymatic activities in the liver were assayed.

Subcellular fractionation. Liver subcellular fractionation was performed by the differential centrifugation method as described previously (9) by the method first reported by Lebsack et al. (6). The liver was homogenized in four volumes of cold $10 \mathrm{~mm}$ Tris- $\mathrm{HCl}$ buffer, $\mathrm{pH} 7.4$, containing $0.25 \mathrm{M}$ sucrose and $1 \mathrm{~mm}$ mercaptoethanol and centrifuged at $750 \times g$ for $10 \mathrm{~min}$. The supernatant was recentrifuged at $10,000 \times g$ for $20 \mathrm{~min}$, and the resultant supernatant was used for the preparation of the microsomal and cytosolic fractions. The precipitate was washed twice with the same buffer solution at $10,000 \times g$ for $10 \mathrm{~min}$ and used as the mitochondrial fraction. The supernatant of this centrifugation step was further spun at $100,000 \times$ $g$ for $60 \mathrm{~min}$ and the supernatant was used as the cytosolic fraction. The resultant precipitate was washed with $0.15 \mathrm{M} \mathrm{KCl}$ at $100,000 \times g$ for $60 \mathrm{~min}$ and used as the microsomal fraction. Each fraction was kept at $-70^{\circ} \mathrm{C}$ until enzymatic activities were assayed.

Vol. 41, No. 5, 1995 
Cytosolic $A D H$. Cytosolic ADH activity was assayed spectrophotometrically by measuring NADH production (15). The specific activity is expressed as $\mu$ moles of $\mathrm{NADH} / \mathrm{min} / \mathrm{mg}$ protein.

MEOS. The activity of MEOS was assayed as described previously (9) by the method first reported by Klein et al. (16). Specific activity is expressed as nmoles of acetaldehyde $/ \mathrm{min} / \mathrm{mg}$ protein.

Microsomal cytochrome P-450. The content of microsomal cytochrome P-450 was assayed as described by Omura and Sato (17) and is expressed as nmoles of cytochrome $\mathrm{P}-450 / \mathrm{mg}$ protein.

Microsomal aniline hydroxylase. Microsomal aniline hydroxylase activity was assayed as described previously (9) by the method first reported by Brodie and Axelrod (18). Specific activity is expressed as nmoles of $p$-aminophenol $/ \mathrm{min} / \mathrm{mg}$ protein.

Aldehyde dehydrogenase $(A l D H)$. The activities of AlDH in the mitochondrial, microsomal and cytosolic fractions were assayed as described previously ( 9 ) by the method first reported by Lebsack et al. (6), except that the acetaldehyde concentration was $5 \mathrm{mM}$ for total, $300 \mu \mathrm{M}$ for high- $K_{\mathrm{m}}$ and $50 \mu \mathrm{M}$ for low- $K_{\mathrm{m}}$ enzymes. Two $\mu \mathrm{M}$ rotenone was added to inhibit NADH oxidase for the mitochondrial AlDH assay. 4-Methylpyrazole was added at a concentration of $200 \mu \mathrm{M}$ to inhibit ADH activity for microsomal and cytosolic AlDH assays. Specific activity is expressed as nmoles of $\mathrm{NADH} / \mathrm{min} / \mathrm{mg}$ protein.

Protein. Protein content was determined by the biuret method (19) with bovine serum albumin (Sigma Chemical Co.) as the standard.

Statistical analysis. The statistical significance of differences between the values of groups were performed by analysis of variance (ANOVA) coupled with Duncan's new multiple range test (20).

\section{RESULTS}

Changes in body weight during chronic ethanol administration

As shown in Fig. 1, in both controls and ethanols, $\mathrm{C} 3 \mathrm{H} / \mathrm{He}$ mice showed the highest body weight among all three strains throughout the experimental period. Although, in both controls and ethanols, the initial body weight of DBA and C57BL mice were almost equivalent (Table 3), those of C57BL mice were the lowest among all three strains at the end of the experiment. Following chronic administration of ethanol, the body weight of $\mathrm{C} 3 \mathrm{H} / \mathrm{He}$ mice tended to increase compared to controls after 35 days, that of DBA mice tended to decrease, and that of C57BL mice remained almost the same as controls (Fig. 1).

\section{Changes in food and liquid consumption during chronic ethanol administration}

The amounts of food and liquid consumption by two mice in a cage in each group for a month were measured and were calculated per mouse. The value is expressed as the mean amount taken per mouse per day during that period. 


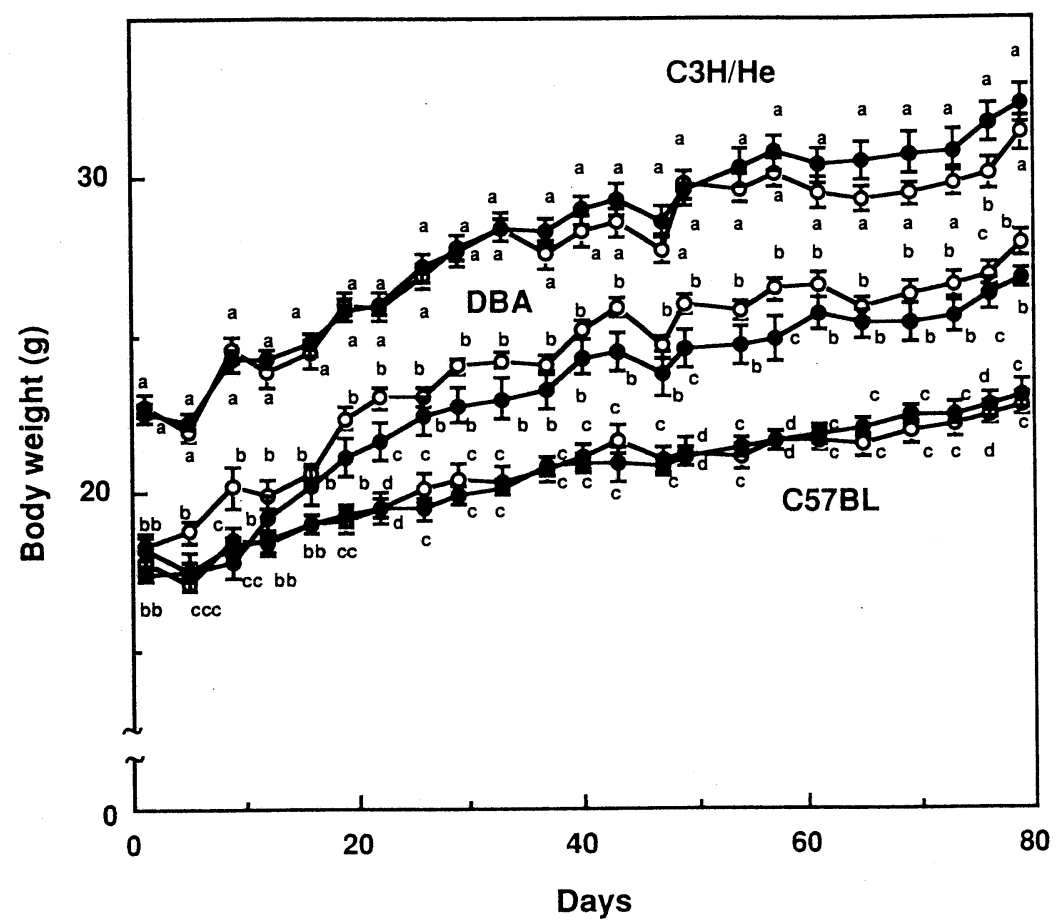

Fig. 1. Changes in body weight of male C57BL, DBA and $\mathrm{C} 3 \mathrm{H} / \mathrm{He}$ mice during chronic administration of ethanol. Water $(\bigcirc$ : Control) or $10 \%(v / v)$ ethanol (๑: Ethanol) was given ad libitum for 80 days. Values are $\mathrm{M} \pm \mathrm{SE}$ of 10 mice. Mean values at each time point not sharing the same superscript or subscript letter are significantly different at $p<0.05$ by Duncan's new multiple range test.

As shown in Fig. 2, in the controls, $\mathrm{C} 3 \mathrm{H} / \mathrm{He}$ mice consumed the largest amount of both food and liquid, C57BL mice consumed the least and DBA mice were intermediate between these two extremes throughout the experimental period. The amount of food consumed in all three strains decreased significantly following chronic administration of ethanol. In the ethanol groups of C57BL and C57BL mice, liquid consumption did not change compared to controls, while that in the ethanol group of DBA mice decreased markedly compared to controls after the first, second or third months.

\section{Changes in energy intake during chronic ethanol administration}

Energy intake was calculated from amounts of food and liquid consumption, using the values of $358 \mathrm{kcal} / 100 \mathrm{~g}$ of MF food and $7 \mathrm{kcal} / \mathrm{g}$ of ethanol. As shown in Table 1, the energy intake of C57BL mice showed almost no change throughout the experimental period, that of DBA mice decreased markedly in the first month followed by a gradual recovery, and that of $\mathrm{C} 3 \mathrm{H} / \mathrm{He}$ mice tended to increase in the first, the second and third months. In both controls and ethanols, energy intakes of 


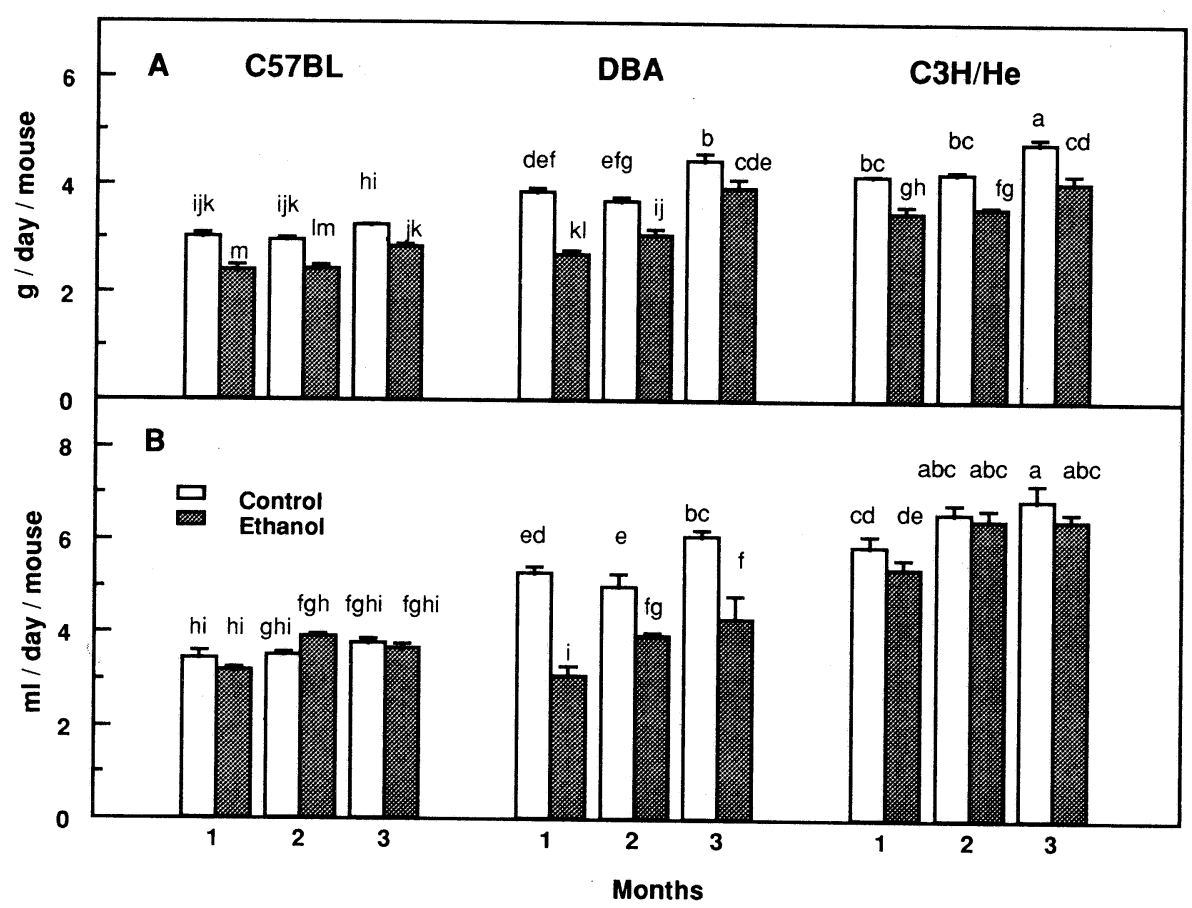

Fig. 2. Changes in food (A) and liquid (B) consumption in male C57BL, DBA and $\mathrm{C} 3 \mathrm{H} / \mathrm{He}$ mice during chronic administration of ethanol. Water (Control) or $10 \%(\mathrm{v} / \mathrm{v})$ ethanol (Ethanol) was given ad libitum for 80 days. Total amount of consumption of two mice in a cage was measured and the consumption per mouse was calculated. Values are mean consumption \pm SE of 5 mice for the first month (1), second month (2) and third month (3), respectively, in units of $\mathrm{g} /$ day/mouse for food and $\mathrm{ml} /$ day/mouse for liquid. Values in food or liquid consumption not sharing the same letter above bars are significantly different $p<0.05$ by Duncan's new multiple range test.

$\mathrm{C} 3 \mathrm{H} / \mathrm{He}$ mice showed the highest values, and those of C57BL mice showed the lowest, and again the DBA were intermediate throughout the experimental period.

Total liquid consumption and ethanol intake per gram of body weight during chronic ethanol administration

As shown Table 2, total amount of water consumption $\mathrm{ml} / \mathrm{g}$ of body weight of $\mathrm{C} 3 \mathrm{H} / \mathrm{He}$ or DBA mice was higher than that of C57BL mice. The total amount of ethanol consumption $\mathrm{ml} / \mathrm{g}$ of body weight of $\mathrm{C} 3 \mathrm{H} / \mathrm{He}$ mice showed a higher value than that of C57BL or DBA mice. The total consumption of ethanol solution of DBA mice decreased significantly compared to control (water). The ratio of the amount of consumption of $10 \%(\mathrm{v} / \mathrm{v})$ ethanol solution/control (water) of C57BL, DBA or $\mathrm{C} 3 \mathrm{H} / \mathrm{He}$ mice was calculated at $1.00,0.73$ or 0.91 , respectively. Total ethanol intake $\mathrm{g} / \mathrm{g}$ of body weight of the mice was calculated from the total amount 
Table 1. Changes in energy intake in male C57BL, DBA and $\mathrm{C} 3 \mathrm{H} / \mathrm{He}$ mice during chronic ethanol treatment.

\begin{tabular}{lccc}
\hline \multicolumn{1}{c}{ Months } & 1 & 2 & 3 \\
\hline C57BL & & $(\mathrm{kcal} / \mathrm{day} / \mathrm{mouse})$ & \\
Control & $10.8 \pm 0.3^{\mathrm{j}}$ & $10.6 \pm 0.2^{\mathrm{j}}$ & $11.5 \pm 0.1^{\mathrm{ij}}$ \\
Ethanol & $10.3 \pm 0.5^{\mathrm{j}}$ & $10.8 \pm 0.4^{\mathrm{j}}$ & $12.2 \pm 0.2^{\mathrm{hi}}$ \\
DBA & & & \\
Control & $13.8 \pm 0.3^{\mathrm{fg}}$ & $13.2 \pm 0.3^{\mathrm{gh}}$ & $15.9 \pm 0.6^{\mathrm{bcde}}$ \\
Ethanol & $11.4 \pm 0.3^{\mathrm{jj}}$ & $13.1 \pm 0.5^{\mathrm{gh}}$ & $16.4 \pm 0.9^{\mathrm{bc}}$ \\
C3H/He & & & \\
Control & $14.9 \pm 0.1^{\mathrm{ef}}$ & $15.1 \pm 0.2^{\mathrm{de}}$ & $17.1 \pm 0.4^{\mathrm{ab}}$ \\
Ethanol & $15.4 \pm 0.5^{\mathrm{cde}}$ & $16.3 \pm 0.4^{\mathrm{bcd}}$ & $18.0 \pm 0.7^{\mathrm{a}}$ \\
\hline Two way ANOVA & & & \\
A & $p<0.001$ & $p<0.001$ & $p<0.001$ \\
B & $p<0.05$ & $\mathrm{NS}$ & $\mathrm{NS}$ \\
A $\times$ B & $p<0.001$ & $\mathrm{NS}$ & $\mathrm{NS}$ \\
\hline
\end{tabular}

Food (MF, Oriental Yeast Co., Ltd., Tokyo), water (Control) or 10\% (v/v) ethanol (Ethanol) was given ad libitum for 80 days. Energy intake was calculated from the amounts of food and liquid consumed using values of $358 \mathrm{kcal} / 100 \mathrm{~g}$ MF and $7 \mathrm{kcal} / \mathrm{g}$ ethanol as conversion factors. Values are $\mathbf{M} \pm \mathrm{SE}$ of 5 mice. Values not sharing the same superscript letter are significantly different at $p<0.05$ by Duncan's new multiple range test. A, Strain effect; B, Ethanol effect; NS, not significant.

Table 2. Total liquid consumption and ethanol intake per gram of body weight during chronic ethanol treatment.

\begin{tabular}{|c|c|c|c|c|}
\hline \multirow[t]{2}{*}{ Strain } & \multicolumn{2}{|c|}{$\begin{array}{c}\text { Liquid } \\
\text { (ml/g of body weight) }\end{array}$} & \multirow[t]{2}{*}{$\mathrm{E} / \mathrm{C}$} & \multirow{2}{*}{$\begin{array}{c}\text { Ethanol } \\
\text { (g/g of body weight) }\end{array}$} \\
\hline & Control & Ethanol & & \\
\hline C57BL & $12.3 \pm 0.1^{c}$ & $12.3 \pm 0.3^{\mathrm{c}}$ & 1.00 & $0.97 \pm 0.03^{b}$ \\
\hline DBA & $15.2 \pm 0.3^{\mathrm{ab}}$ & $11.1 \pm 0.5^{\mathrm{c}}$ & 0.73 & $0.88 \pm 0.04^{b}$ \\
\hline $\mathrm{C} 3 \mathrm{H} / \mathrm{He}$ & $16.2 \pm 0.8^{a}$ & $14.7 \pm 0.4^{b}$ & 0.91 & $1.16 \pm 0.03^{\mathrm{a}}$ \\
\hline \multicolumn{2}{|c|}{$\begin{array}{l}\text { Two-way ANOVA } \\
\text { Liquid }\end{array}$} & $\underset{p<0.001}{\mathbf{A}}$ & $\begin{array}{c}\text { B } \\
p<0.001\end{array}$ & $\begin{array}{c}\mathbf{A} \times \mathbf{B} \\
p<0.001\end{array}$ \\
\hline
\end{tabular}

Values are $\mathrm{M} \pm \mathrm{SE}$ of 5 mice. Water (Control) and $10 \%(\mathrm{v} / \mathrm{v})$ ethanol (Ethanol) were given ad libitum for 80 days. Values in liquid or ethanol not sharing the same superscript letter are significantly different at $p<0.05$ by Duncan's new multiple range test. E/C, Ethanol/Control; A, Strain effect; B, Ethanol effect.

of $10 \%(\mathrm{v} / \mathrm{v})$ ethanol solution drinking during the experimental period. Total ethanol intake $\mathrm{g} / \mathrm{g}$ of body weight of $\mathrm{C} 3 \mathrm{H} / \mathrm{He}$ mice showed the highest value among all three strains and that of C57BL mice tended to show a higher value than that of DBA mice. 
Changes in body and liver weights after chronic ethanol administration

As shown in Table 3, in both controls and ethanols, the body weight of C57BL mice was the lowest and that of $\mathrm{C} 3 \mathrm{H} / \mathrm{He}$ mice was the highest among all three strains. The body weights of $\mathrm{C} 57 \mathrm{BL}$ and $\mathrm{C} 3 \mathrm{H} / \mathrm{He}$ mice tended to increase after chronic ethanol administration of ethanol. The liver weight of $\mathrm{C} 57 \mathrm{BL}$ and $\mathrm{C} 3 \mathrm{H} / \mathrm{He}$

Table 3. Mean weights of body and liver in male C57BL, DBA and $\mathrm{C} 3 \mathrm{H} / \mathrm{He}$ mice after chronic ethanol treatment.

\begin{tabular}{lccc}
\hline & C57BL & DBA & C3H/He \\
\hline Body weight (g) & & & \\
Control & $22.7 \pm 0.4^{\mathrm{c}}$ & $26.3 \pm 0.7^{\mathrm{b}}$ & $31.3 \pm 0.5^{\mathrm{a}}$ \\
Ethanol & $23.8 \pm 0.5^{\mathrm{c}}$ & $26.1 \pm 0.5^{\mathrm{b}}$ & $32.8 \pm 0.7^{\mathrm{a}}$ \\
Liver weight (g) & $1.03 \pm 0.04^{\mathrm{d}}$ & $1.22 \pm 0.07^{\mathrm{c}}$ & $1.50 \pm 0.04^{\mathrm{b}}$ \\
Control & $1.18 \pm 0.02^{\mathrm{c}}$ & $1.25 \pm 0.06^{\mathrm{c}}$ & $1.73 \pm 0.05^{\mathrm{a}}$ \\
Ethanol & $\mathrm{A}$ & $\mathrm{B}$ & $\mathrm{A} \times \mathrm{B}$ \\
\hline Two-way ANOVA & $p<0.001$ & $\mathrm{NS}$ & $\mathrm{NS}$ \\
Body weight & $p<0.001$ & $p<0.01$ & $\mathrm{NS}$ \\
Liver weight & & & \\
\hline
\end{tabular}

Water (Control) or $10 \%(\mathrm{v} / \mathrm{v})$ ethanol (Ethanol) was given ad libitum for 80 days. Values are $\mathbf{M} \pm \mathrm{SE}$ of 10 mice. Body and liver weights of mice sacrificed at 10 a.m. were measured. Values in body or liver weight not sharing the same superscript letter are significantly different at $p<0.05$ by Duncan's new multiple range test. A, Strain effect; B, Ethanol effect; NS, not significant.

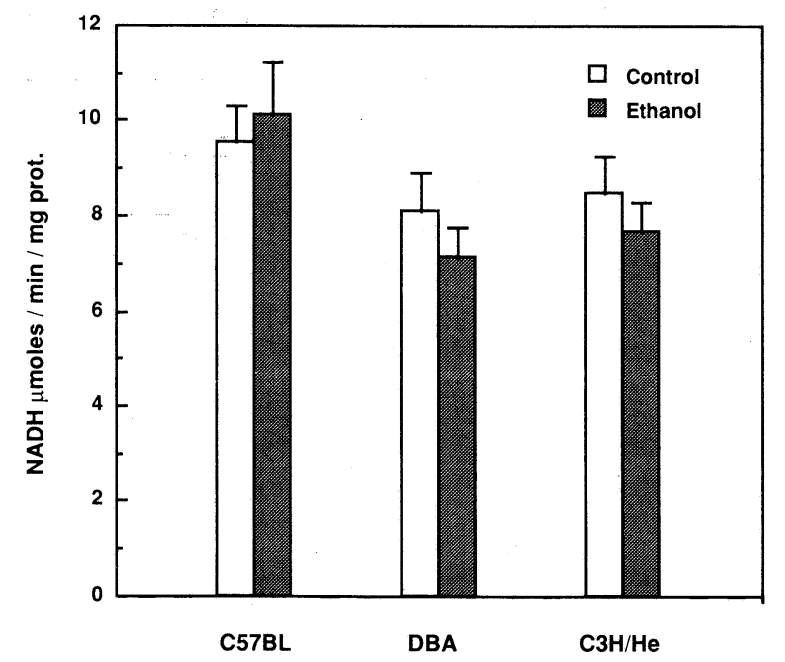

Fig. 3. Changes in specific activities of cytosolic ADH in livers of male C57BL, DBA and $\mathrm{C} 3 \mathrm{H} / \mathrm{He}$ mice after chronic administration of ethanol. Water (Control) or $10 \%(\mathrm{v} / \mathrm{v})$ ethanol (Ethanol) was given ad libitum for 80 days. Values are $\mathbf{M} \pm \mathbf{S E}$ of 10 mice. 
mice increased significantly, although that of DBA mice showed almost no change after chronic administration of ethanol.

\section{Changes in ADH activity in liver cytosol}

As shown in Fig. 3, the specific activity of ADH in the liver cytosol tended to be the highest in C57BL mice and the lowest in DBA mice among all three strains, but the difference was not significant. Chronic administration of ethanol did not change the specific activity of ADH in any mouse strain.

Changes in activities of MEOS and aniline hydroxylase, and in content of cytochrome $P-450$ in liver microsomes

As shown in Table 4, in both controls and ethanols, the MEOS activity of the liver microsomes in C57BL mice showed approximately a 2-fold higher specific activity compared to that of $\mathrm{DBA}$ or $\mathrm{C} 3 \mathrm{H} / \mathrm{He}$ mice. It showed almost no change in all three strains following chronic administration of ethanol.

In the controls, the content of cytochrome P-450 of the microsome in C57BL mice was lower than that of $\mathrm{C} 3 \mathrm{H} / \mathrm{He}$ mice.

Table 4. Specific activities of microsomal ethanol-oxidizing system (MEOS) and aniline hydroxylase, and contents of cytochrome P-450 in the microsomes from the liver of male C57BL, DBA and $\mathrm{C} 3 \mathrm{H} / \mathrm{He}$ mice after chronic ethanol treatment.

\begin{tabular}{llcc}
\hline & C57BL & DBA & C3H/He \\
\hline $\begin{array}{l}\text { MEOS } \\
\text { (nmoles/min/mg prot.) }\end{array}$ & & & \\
Control & $2.021 \pm 0.196^{\mathrm{a}}(n=5)$ & $1.084 \pm 0.082^{\mathrm{b}}(n=5)$ & $1.060 \pm 0.047^{\mathrm{b}}(n=5)$ \\
Ethanol & $2.417 \pm 0.346^{\mathrm{a}}(n=5)$ & $1.095 \pm 0.089^{\mathrm{b}}(n=5)$ & $1.073 \pm 0.039^{\mathrm{b}}(n=5)$ \\
Cytochrome P-450 & & & \\
$\quad$ (nmoles/min/mg prot.) & & & \\
Control & $0.508 \pm 0.026^{\mathrm{b}}(n=5)$ & $0.646 \pm 0.045^{\mathrm{ab}}(n=6)$ & $0.665 \pm 0.035^{\mathrm{a}}(n=6)$ \\
Ethanol & $0.612 \pm 0.075^{\mathrm{ab}}(n=6)$ & $0.618 \pm 0.038^{\mathrm{ab}}(n=5)$ & $0.749 \pm 0.050^{\mathrm{a}}(n=6)$ \\
Aniline hydroxylase & & & \\
$\quad$ (nmoles/min/mg prot.) & & & \\
Control & $0.235 \pm 0.022^{\mathrm{b}}(n=6)$ & $0.238 \pm 0.028^{\mathrm{b}}(n=6)$ & $0.229 \pm 0.027^{\mathrm{b}}(n=6)$ \\
Ethanol & $0.380 \pm 0.037^{\mathrm{a}}(n=7)$ & $0.293 \pm 0.033^{\mathrm{ab}}(n=6)$ & $0.376 \pm 0.043^{\mathrm{a}}(n=7)$ \\
\hline Two-way ANOVA & $\mathrm{A}$ & $\mathrm{B}$ & $\mathrm{A} \times \mathrm{B}$ \\
MEOS & $p<0.001$ & $\mathrm{NS}$ & $\mathrm{NS}$ \\
Cytochrome P-450 & $p<0.05$ & $\mathrm{NS}$ & $\mathrm{NS}$ \\
Aniline hydroxylase & $\mathrm{NS}$ & $p<0.001$ & $\mathrm{NS}$ \\
\hline
\end{tabular}

Water (Control) or 10\% (v/v) ethanol (Ethanol) was given ad libitum for 80 days. Activity of MEOS was measured in the presence of $1 \mathrm{~mm}$ sodium azide to inhibit possible contaminating catalase activity. Values are $M \pm S E$ of 5-7 mice. Values in activities of MEOS, aniline hydroxylase, or contents of cytochrome P-450 not sharing the same superscript letter are significantly different at $p<0.05$ by Duncan's new multiple range test. A, Strain effect; B, Ethanol effect; NS, not significant. 
On the other hand, the specific activity of aniline hydroxylase in the liver microsomes was almost equivalent in all three strains in the controls and increased significantly in $\mathrm{C} 57 \mathrm{BL}$ and $\mathrm{C} 3 \mathrm{H} / \mathrm{He}$ mice following chronic administration of ethanol. The content of cytochrome P-450 in the microsomes tended to increase in these strains following chronic administration of ethanol, while DBA mice did not change compared to the controls.

Changes in AlDH activity in liver mitochondrial, microsomal and cytosolic fractions

As shown in Fig. 4, in the mitochondria, the specific activity of total AlDH increased significantly and that of high- $K_{\mathrm{m}}$ AlDH tended to increase in C57BL mice following chronic administration of ethanol. These $\mathrm{AlDH}$ activities in $\mathrm{C} 3 \mathrm{H} / \mathrm{He}$ and DBA mice also tended to increase but not significantly so following chronic administration of ethanol. The specific activities of low- $K_{\mathrm{m}}$ AlDH did not change in any mouse strain following chronic administration of ethanol.

As shown in Fig. 5, the specific activity of both high- $K_{\mathrm{m}}$ and total microsomal AlDH also markedly increased significantly in C57BL mice and tended to increase slightly in $\mathrm{C} 3 \mathrm{H} / \mathrm{He}$ mice following chronic administration of ethanol. The specific activity of these AlDH in DBA mice showed no differences. The low- $K_{\mathrm{m}}$ AlDH

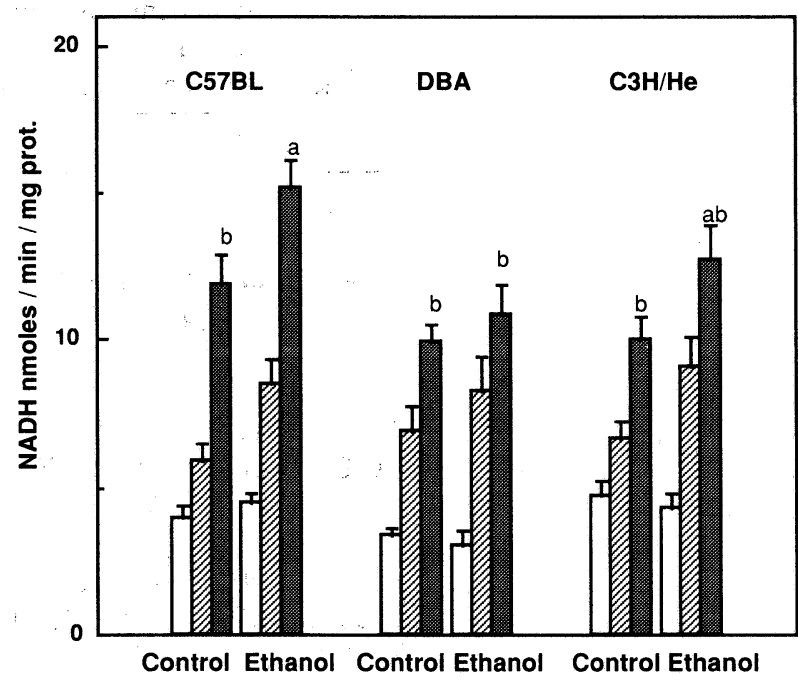

Fig. 4. Changes in specific activities of mitochondrial AlDH in livers of male C57 $\mathrm{BL}, \mathrm{DBA}$ and $\mathrm{C} 3 \mathrm{H} / \mathrm{He}$ mice after chronic administration of ethanol. Water (Control) or $10 \%(\mathrm{v} / \mathrm{v})$ ethanol (Ethanol) was given ad libitum for 80 days. AlDH was measured in the presence of $2 \mu \mathrm{M}$ rotenone to inhibit possible contaminating NADH oxidase activity. Total activity (12) was measured with 5 $\mathrm{mM}$ acetaldehyde substrate, high- $K_{\mathrm{m}}$ activity (ש) with $300 \mu \mathrm{M}$ and low- $K_{\mathrm{m}}$ activity ( $\square)$ with $50 \mu \mathrm{M}$. Values are $\mathrm{M} \pm \mathrm{SE}$ of 10 mice. Values in total activities not sharing the same letter above bars are significantly different at $p<0.05$ by Duncan's new multiple range test. 


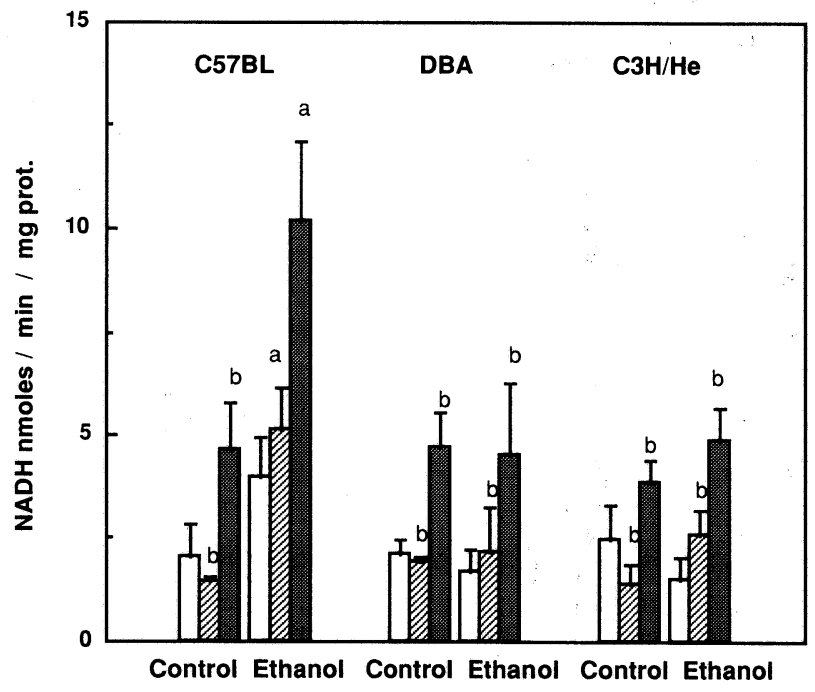

Fig. 5. Changes in specific activities of microsomal AlDH in livers of male C57BL, DBA and $\mathrm{C} 3 \mathrm{H} / \mathrm{He}$ mice after chronic administration of ethanol. Water (Control) or $10 \%(\mathrm{v} / \mathrm{v})$ ethanol (Ethanol) was given ad libitum for 80 days. AlDH was measured in the presence of $200 \mu \mathrm{M}$ 4-methylpyrazole to inhibit possible contaminating ADH activity. Total activity (1), high- $K_{\mathrm{m}}$ activity (河) and low$K_{\mathrm{m}}$ activity $(\square)$ were measured with the concentrations of acetaldehyde as described in the legend of Fig. 4. Values are $M \pm S E$ of 5 mice. Values in high$K_{\mathrm{m}}$ or total activities not sharing the same letter above bars are significantly different at $p<0.05$ by Duncan's new multiple range test.

activities in C57BL mice tended to increase following chronic administration of ethanol.

As shown in Fig. 6, the specific activity of low- $K_{\mathrm{m}}$, high- $K_{\mathrm{m}}$ and total cytosolic AlDH showed no differences following chronic administration of ethanol in any mouse strain studied.

\section{DISCUSSION}

It is well known that C57BL mice show a preference for drinking alcohol solution, while DBA mice show significant avoidance. In our study, C57BL and $\mathrm{C} 3 \mathrm{H} / \mathrm{He}$ mice also preferred to drink $10 \%(\mathrm{v} / \mathrm{v})$ ethanol solution and consumed more of it compared to DBA mice (Fig. 2, Table 2). $\mathrm{C} 3 \mathrm{H} / \mathrm{He}$ mice showed the largest ethanol intake $\mathrm{g} / \mathrm{g}$ of body weight among all three strains, DBA mice tended to show the smallest among them and consumption by C57BL mice tended to be between these two extremes during chronic administration of ethanol (Table 2). The liver weight of $\mathrm{C} 57 \mathrm{BL}$ and $\mathrm{C} 3 \mathrm{H} / \mathrm{He}$ mice increased significantly following chronic administration of ethanol (Table 3). Both mice strains took the same or a 


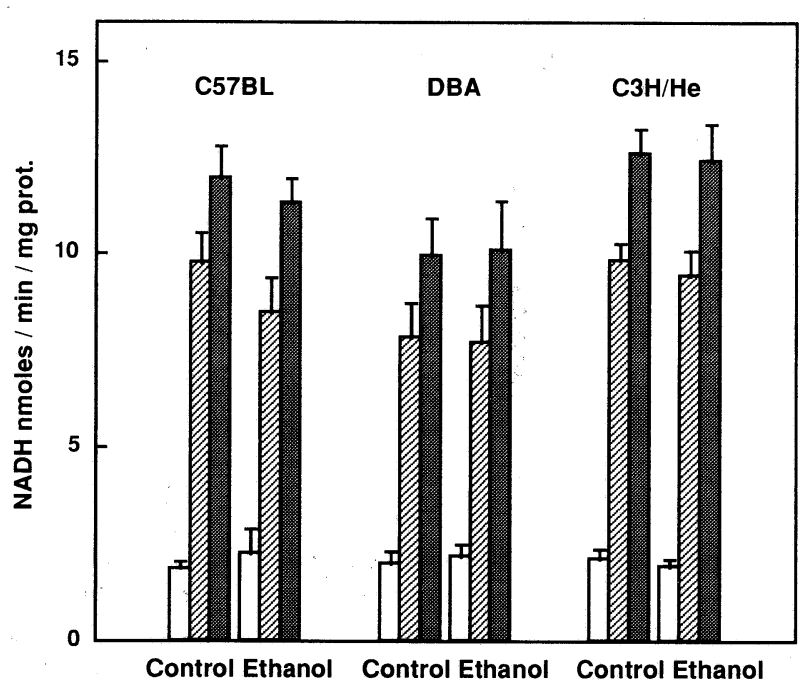

Fig. 6. Changes in specific activities of cytosolic AlDH in livers of male C57BL, DBA and $\mathrm{C} 3 \mathrm{H} / \mathrm{He}$ mice after chronic administration of ethanol. Water (Control) or $10 \%(\mathrm{v} / \mathrm{v})$ ethanol (Ethanol) was given ad libitum for 80 days. AlDH was measured in the presence of $200 \mu \mathrm{M}$ 4-methylpyrazole to inhibit possible

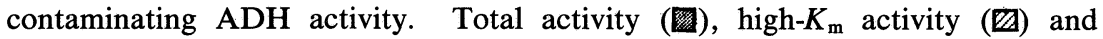
low- $K_{\mathrm{m}}$ activity $(\square)$ were measured with the concentrations of acetaldehyde as described in the legend of Fig. 4. Values are $M \pm S E$ of 10 mice.

large amount of $10 \%(\mathrm{v} / \mathrm{v})$ ethanol solution compared to control (water) (Table 2, Fig. 2). Although all three strains showed decreased food consumption (Fig. 2), the intakes of total energy from food and ethanol in the three strains of mice did not decrease except in the first month in the DAB mice following chronic administration of ethanol. The body weight of $\mathrm{C} 3 \mathrm{H} / \mathrm{He}$ mice, which consumed more energy than the control mice, tended to increase following chronic administration of ethanol (Tables 1-3).

Ethanol crosses cellular membranes by simple diffusion. The in vivo oxidation of ethanol takes place almost exclusively in the liver, the first step of which is mediated by ADH localized in the cytosol which has a very low- $K_{\mathrm{m}}$ for ethanol. Although the ADH activity of C57BL mice tended to be the highest and that of DBA mice tended to be the lowest among the three strains studied, no induction of ADH by chronic administration of ethanol was observed in any of these strains (Fig. 3).

Metabolism by ADH activity is clearly the major pathway for ethanol degradation in vivo, but another pathway (MEOS), active at very high blood alcohol concentrations, has been reported (21). Oxidation of ethanol was also shown to be carried out by MEOS, not by catalase, in an ADH-deficient deermouse (22). The MEOS is thought to be very similar to the mixed function oxidase system (MFO) 
which is responsible for the metabolism of many drugs (detoxification) in vivo. The MEOS was shown to be induced in the liver by chronic consumption of the ethanol in humans (23), rabbits (4), and rats (24). Although the MEOS activity of C57BL mice was the highest among all strains tested here, no marked induction by the chronic administration of ethanol was observed in any of these three strains (Table 4). The principal factor for the induction of MEOS seemed to be cytochrome P450IIE1 (3) because it was induced by ethanol administration, the expression of which was induced by obesity (25), fasting (26), diabetes mellitus (27), and a variety of drugs $(28,29)$. The content of cytochrome P-450 was slightly but not significantly elevated by chronic administration of ethanol in $\mathrm{C} 57 \mathrm{BL}$ and $\mathrm{C} 3 \mathrm{H} / \mathrm{He}$ mice (Table 4). As there are many isozymes of cytochrome P-450, determination of total cytochrome P-450 content can not reveal the precise nature of the induction. On the other hand, significant induction of aniline hydroxylase activity was observed following chronic administration of ethanol in $\mathrm{C} 57 \mathrm{BL}$ and $\mathrm{C} 3 \mathrm{H} / \mathrm{He}$ mice, and a slight increase was also observed in DBA (Table 4). Thus, the content of cytochrome P-450IIE1 in the hepatic microsomes of these mice seemed to be induced by chronic administration of ethanol. Kunitoh et al. reported (30) that CYP1A2 and CYP2E1 contributed to MEOS activity. It is interesting that the liver microsomes of C57BL mice exhibited approximately a 2-fold higher specific activity of MEOS compared to that of DBA and of $\mathrm{C} 3 \mathrm{H} / \mathrm{He}$ mice in both controls and ethanols (Table 4). Thus, it seemed that MEOS activity in C57BL mice also included CYP1A2 or other cytochrome P-450s.

The second step in the metabolism of the ethanol is mediated by AlDH, which oxidizes acetaldehyde to acetate. It is believed that the main pathway is located in the liver mitochondria. Although AlDH activity in the mitochondria was reported to be decreased by chronic administration of ethanol in rats and baboons (6), in our experiments with mice, total AlDH activity increased significantly and high- $K_{\mathrm{m}}$ AlDH activity tended to increase in C57BL mice. These AlDH activities in the mitochondria tended to increase in $\mathrm{C} 3 \mathrm{H} / \mathrm{He}$ mice that consumed the largest amount of ethanol solution per $\mathrm{g}$ of body weight among all three strains, but did not change in DBA mice (Fig. 4). The low- $K_{\mathrm{m}}$ AlDH activities in the mitochondria did not change in any strain following chronic administration of ethanol. It seemed that the increase in total AlDH activity in the mitochondria of C57BL mice was related with the increase in high- $K_{\mathrm{m}}$ AlDH activity. Agarwal et al. (31) reported that the activity of hepatic AlDH is reduced in subjects with alcoholic liver disease. Our mice here seemed not to have alcoholic liver disease. The degree of alcohol intoxication might be related to these differences and further studies are currently in progress in our laboratory to clarify this point.

AlDH activity was also found in the microsomes in mice (Fig. 5). It is interesting that the high $-K_{\mathrm{m}}$ and total AlDH activities in the microsomes of C57BL mice increased significantly following chronic administration of ethanol. However, the AlDH activities in the microsomes of $\mathrm{C} 3 \mathrm{H} / \mathrm{He}$ mice did not increase markedly, even though their ethanol intake was the largest among all three strains, and no 
change was observed in DBA mice (Fig. 5). The increase in total AlDH activity in the microsomes of C57BL mice was related to the increase in high- $K_{\mathrm{m}}$ AlDH activity. It was reported that the capacity of acetaldehyde oxidation of C57BL mice liver was greater than that of DBA mice $(13,14)$. In this study also, following chronic administration of ethanol, oxidation of acetaldehyde in the microsomes in the liver of C57BL mice increased but that from DBA mice did not. Previously, we reported that high- $K_{\mathrm{m}}$ AlDH activity in the microsomes was increased significantly at night by chronic administration of ethanol in $\mathrm{C} 3 \mathrm{H} / \mathrm{He}$ mice (9). The difference in the results of our previous and present studies seems to be due to the different times of sacrifice of mice (circadian rhythm). A possible pathway for acetaldehyde oxidation by the microsomal cytochrome P-450 has been reported (32), and Terelius et al. reported (33) that liver microsomes from starved and acetone-treated rats catalyzed NADPH-supported metabolism of acetaldehyde at a rate 8-fold higher than control microsomes and that CYP2E1 was an aldehyde oxidase. CYP2E1 or the other cytochrome P-450 isozymes might metabolize acetaldehyde in the liver microsomes of mice. Studies are currently in progress with our mice.

Eriksson et al. reported (34) that the activity of a high- $K_{\mathrm{m}}$ AlDH in the liver cytosol was increased by phenobarbital induction, but cytosolic AlDH played only a minor role in the oxidation of acetaldehyde during ethanol metabolism. In our study here, although AlDH activity was found in the liver cytosolic fractions of all three strains, the activities of both high $-K_{\mathrm{m}}$ and low- $K_{\mathrm{m}}$ enzymes did not change following chronic ethanol administration (Fig. 6). The oxidation of ethanol in hepatic microsomes of $\mathrm{C} 57 \mathrm{BL}$ and of $\mathrm{C} 3 \mathrm{H} / \mathrm{He}$ mice, which consumed a large amount of $10 \%(\mathrm{v} / \mathrm{v})$ ethanol solution, increased but that of DBA mice which consumed a small amount of it did not change, although there was no significant difference between the ethanol intakes $\mathrm{g} / \mathrm{g}$ of body weight of C57BL and of DBA mice (Fig. 2, Tables 2, 4). The oxidation of acetaldehyde in the mitochondria and in the microsomes of C57BL mice increased, but that in $\mathrm{C} 3 \mathrm{H} / \mathrm{He}$ and DBA mice did not increase (Figs. 2, 4, 5, Table 2). These results suggested that C57BL mice had the strongest sensitivity to both oxidation of ethanol and acetaldehyde among all three strains. It was reported that the capacity of acetaldehyde oxidation of C57BL mice liver was greater than that of DBA mice $(13,14)$. It seemed that, in the metabolic pathway of ethanol of the liver of mice, the increase in enzyme activity related to ethanol oxidation in the microsomes, was responsible for the amount of ethanol intake, while the increases of activities of enzymes involved in acetaldehyde oxidation in the microsome and in the mitochondria were responsible for the mouse strain difference. It was unknown whether the increases in the liver weight of $\mathrm{C} 57 \mathrm{BL}$ and $\mathrm{C} 3 \mathrm{H} / \mathrm{He}$ mice on drinking ethanol (Table 3) were responsible for the enzyme induction because the lipid content in the liver of mice was not examined.

\section{REFERENCES}

1) Lieber, C. S., and DeCarli, L. M. (1970): Hepatic microsomal ethanol-oxidizing 
system. In vitro characteristics and adaptive properties in vivo. J. Biol. Chem., 245, 2505-2512.

2) Teschke, R., Hasemura, Y., and Lieber, C. S. (1974): Hepatic microsomal ethanoloxidizing system: Solubilization, isolation, and characterization. Arch. Biochem. Biophys., 163, 404-415.

3) Koop, D. R., Nordblom, G. D., and Coon, M. J. (1984): Immunochemical evidence for a role of cytochrome P-450 in liver microsomal ethanol oxidation. Arch. Biochem. Biophys., 235, 228-238.

4) Koop, D. R., Morgan, E. T., Tarr, G. E., and Coon, M. J. (1982): Purification and characterization of a unique isozyme of cytochrome P-450 from liver microsomes of ethanol-treated rabbits. J. Biol. Chem., 257, 8472-8480.

5) Forkert, P. G., Massey, T. E., Jones, A. B., Park, S. S., Gelboin, H. V., and Anderson, L. M. (1991): Distribution of cytochrome CYP2E1 in murine liver after ethanol and acetone administration. Carcinogenesis, 12, 2259-2268.

6) Lebsack, M. E., Gordon, E. R., and Lieber, C. S. (1981): Effect of chronic ethanol consumption on aldehyde dehydrogenase activity in the baboon. Biochem. Pharmacol., 30, 2273-2277.

7) Shirota, F. N., DeMaster, E. G., and Nagasawa, H. T. (1982): Studies of the cyanamide-ethanol interaction, dimethylcyanamide as an inhibitor of aldehyde dehydroxylase in vivo. Biochem. Pharmacol., 31, 1999-2004.

8) Deimling, M. J., and Schnell, R. C. (1980): Circadian rhythms in the biological response and disposition ethanol in the mouse. J. Pharmacol. Exp. Ther., 213, 1-8.

9) Kishimoto, R., Terasawa, K., Yasuda, M., and Nakata, Y. (1990): Diurnal variations in the enzymes of ethanol-metabolizing pathway in mouse liver under chronic ethanol consumption. J. Jpn. Soc. Nutr. Food Sci., 43, 181-188.

10) Hietanen, E., Malaveille, C., Friedman, F. K., Park, S. S., Bereziat, J. C., Brun, G., Bartsch, H., and Gelboin, H. V. (1986): Monoclonal antibody-directed analysis of cytochrome P-450-dependent monooxygenases and mutagen activation in the livers of DBA/2 and C57BL/6 mice. Cancer Res., 46, 524-531.

11) Cheng, K. C., Gelboin, H. V., Song, B. J., Park, S. S., and Friedman, F. K. (1984): Detection and purification of cytochromes P-450 in animal tissues with monoclonal antibodies. J. Biol. Chem., 259, 12279-12284.

12) Cheng, K. C., Krutzsch, H. C., Grantham, P. H., Park, S. S., Gelboin, H. V., and Friedman, F. K. (1984): Amino-terminal sequence analysis of six cytochrome P-450 isozymes purified by monoclonal antibody directed immunopurification. Biochem. Biophys. Res. Commun., 123, 1201-1208.

13) Sheppard, J. R., Albersheim, P., and McClearn, G. (1970): Aldehyde dehydrogenase and ethanol preference in mice. J. Biol. Chem., 245, 2876-2892.

14) Eriksson, C. J. P., Atkinson, N., Petersen, D., and Deitrich, R. A. (1984): Blood and liver acetaldehyde concentrations during ethanol oxidation in C57 and DBA mice. Biochem. Pharmacol., 33, 2213-2216.

15) Tsukamoto, S. (1988): Alcohol Metabolism, 2nd ed., Shinko-igaku-Shuppansha, Japan, pp. 13-15.

16) Klein, S. M., Cohen, G., Lieber, C. S., and Cederbaum, A. I. (1983): Increased microsomal oxidation of hydroxyl radical scavenging agents and ethanol after chronic consumption of ethanol. Arch. Biochem. Biophys., 223, 425-432.

Vol. 41, No. 5, 1995 
17) Omura, T., and Sato, R. (1964): The carbon monoxide-binding pigment of liver microsomes. J. Biol. Chem., 239, 2370-2378.

18) Brodie, B. B., and Axelrod, J. (1948): The estimation of acetanilide and its metabolic products, aniline, $\mathrm{N}$-acetyl $p$-aminophenol and $p$-aminophenol (free and total conjugated) in biological fluids and tissues. J. Pharmacol. Exp. Ther., 94, 22-28.

19) Gornall, A. G., Bardawill, C. J., and David, M. M. (1948): Determination of serum proteins by means of the biuret reaction. J. Biol. Chem., 177, 751-766.

20) Duncan, D. B. (1957): Multiple range tests for correlated and heteroscedastic means. Biometrics, 13, 164-176.

21) Lieber, C. S. (1976): The metabolism of alcohol. Sci. Am., 234, 25-33.

22) Kato, S., Alderman, J., and Lieber, C. S. (1987): Respective roles of the microsomal ethanol oxidizing system and catalase in ethanol metabolism by deermice lacking alcohol dehydrogenase. Arch. Biochem. Biophys., 254, 586-591.

23) Song, B. J., Gelboin, H. V., Park, S. S., Yang, C. S., and Gonzalez, F. J. (1986): Complementary DNA and protein sequences of ethanol-inducible rat and human cytochrome P-450s. J. Biol. Chem., 261, 16689-16697.

24) Ryan, D. E., Koop, D. R., Thomas, P. E., Coon, M.J., and Levin, W. (1986): Evidence that isoniazid and ethanol induce the same microsomal cytochrome P-450 in rat liver, an isozyme homologous to rabbit liver cytochrome P-450 isozyme 3a. Arch. Biochem. Biophys., 246, 633-644.

25) Raucy, J. L., Lasker, J. M., Kraner, J. C., Salazar, D. E., Lieber, C. S., and Corcoran, G. B. (1990): Induction of cytochrome P-450IIE1 in the obese overfed rat. Mol. Pharmacol., 39, 275-280.

26) Hong, J., Pan, J., Gonzalez, F. J., Gelboin, H. V., and Yang, C. S. (1987): The induction of a specific form of cytochrome P-450 (P-450j) by fasting. Biochem. Biophys. Res. Commun., 142, 1077-1083.

27) Wu, D., and Cederbaum, A. I. (1993): Combined effects of streptozotocin-induced diabetes plus 4-methylprazole treatment on rat liver cytochrome P4502E1. Arch. Biochem. Biophys., 302, 175-182.

28) Koop, D. R., and Casazza, J. P. (1985): Identification of ethanol-inducible P-450 isozyme $3 \mathrm{a}$ as the acetone and acetol monooxygenase of rabbit microsomes. J. Biol. Chem., 260, 13607-13612.

29) Wu, D., and Cederbaum, A. I. (1992): Induction of liver cytochrome P4502E1 by pyrazole and 4-methylpyrazole in neonatal rats. J. Pharmacol. Exp. Ther., 264, 14681473.

30) Kunitoh, S., Tanaka, T., Imaoka, S., Funae, Y., and Monna, Y. (1993): Contribution of cytochrome P450s to MEOS (microsomal ethanol-oxidizing system): A specific and sensitive assay of MEOS activity by HPLC with fluorescence labeling. Alcohol Alcohol., 28, 63-68.

31) Agarwal, D. P., Muller, C., Korencke, C., Mika, U., Harada, S., and Goedde, H. W. (1985): Changes in erythrocyte and liver aldehyde dehydrogenase in alcoholics, in Enzymology of Carbonyl Metabolism, Vol. 2, ed. by Flynn, T. G., and Weiner, H., Alan R. Liss, New York, pp. 113-127.

32) Watanabe, K., Narimatsu, S., Yamamoto, I., and Yoshimura, H. (1991): Oxygenation mechanism in conversion of aldehyde to carboxylic acid catalyzed by a cytochrome P450 isozyme. J. Biol. Chem., 226, 2709-2711. 
33) Terelius, Y., Norsten-Hoog, C., Cronholm, T., and Ingelman-Sundberg, M. (1991): Acetaldehyde as a substrate for ethanol-inducible cytochrome P450 (CYP2E1). Biochem. Biophys. Res. Commun., 179, 689-694.

34) Eriksson, C. J. P., Marselos, M., and Koivula, T. (1975): Role of cytosolic rat liver aldehyde dehydrogenase in the oxidation of acetaldehyde during ethanol metabolism in vivo. Biochem. J., 152, 709-712. 